\title{
Mapping of panda plumage color locus on the microsatellite linkage map of the Japanese quail
}

\author{
Mitsuru Miwa1, Miho Inoue-Murayama*1, Naoki Kobayashi1, \\ Boniface Baboreka Kayang ${ }^{2}$, Makoto Mizutani ${ }^{3}$, Hideaki Takahashi ${ }^{4}$ and \\ Shin'ichi Ito ${ }^{1}$
}

\begin{abstract}
Address: ${ }^{1}$ Faculty of Applied Biological Sciences, Gifu University, Gifu 501-1193, Japan, ${ }^{2}$ Department of Animal Science, College of Agriculture and Consumer Sciences, University of Ghana, Legon, Ghana, ${ }^{3}$ Graduate School of Bioagricultural Sciences, Nagoya University, Nagoya 464-8601, Japan and ${ }^{4}$ National Institute of Agrobiological Sciences, Tsukuba 305-8602, Japan

Email: Mitsuru Miwa - j4111028@guedu.cc.gifu-u.ac.jp; Miho Inoue-Murayama* - miho-i@cc.gifu-u.ac.jp; Naoki Kobayashi - asymmetryrechteboom@ezweb.ne.jp; Boniface Baboreka Kayang - bbkayang@ug.edu.gh; Makoto Mizutani - mizutani@nuagr1.agr.nagoya-u.ac.jp;

Hideaki Takahashi - h.takahashi@nias.affrc.go.jp; Shin'ichi Ito - ito-s@cc.gifu-u.ac.jp

* Corresponding author
\end{abstract}

Published: 12 January 2006

BMC Genetics 2006, 7:2 doi:10.1186/147/-2156-7-2
Received: 15 July 2005

Accepted: 12 January 2006

This article is available from: http://www.biomedcentral.com/l47/-2/56/7/2

(c) 2006 Miwa et al; licensee BioMed Central Ltd.

This is an Open Access article distributed under the terms of the Creative Commons Attribution License (http://creativecommons.org/licenses/by/2.0), which permits unrestricted use, distribution, and reproduction in any medium, provided the original work is properly cited.

\begin{abstract}
Background: Panda $(s)$ is an autosomal recessive mutation, which displays overall white plumage color with spots of wild-type plumage in the Japanese quail (Coturnix japonica). In a previous study, the $s$ locus was included in the same linkage group as serum albumin (Alb) and vitamin-D binding protein (GC) which are mapped on chicken (Gallus gallus) chromosome 4 (GGA4). In this study, we mapped the $s$ locus on the microsatellite linkage map of the Japanese quail by linkage analysis.

Results: Segregation data on the $s$ locus were obtained from three-generation families $(n=106)$. Two microsatellite markers derived from the Japanese quail chromosome 4 (CJA04) and three microsatellite markers derived from GGA4 were genotyped in the three-generation families. We mapped the $s$ locus between GUJ0026 and ABR0544 on CJA04. By comparative mapping with chicken, this locus was mapped between I0.0 Mb and I4.5 Mb region on GGA4. In this region, the endothelin receptor $B$ subtype 2 gene (EDNRB2), an avian-specific paralog of the mammalian endothelin receptor $B$ gene (EDNRB), is located. Because EDNRB is responsible for aganglionic megacolon and spot coat color in mouse, rat and equine, EDNRB2 is suggested to be a candidate gene for the $s$ locus.
\end{abstract}

Conclusion: The $s$ locus and the five microsatellite markers were mapped on CJA04 of the Japanese quail. EDNRB2 was suggested to be a candidate gene for the $s$ locus.

\section{Background}

Panda $(s)$ is an autosomal recessive mutation, which causes overall white with spots of wild-type plumage in the Japanese quail (Coturnix japonica) (Figure 1) [1]. When they hatched, they have several brown spots in head, back and tail. After grew up, the spots become wild-type plumage color. Numbers and patterns of spots do not change in their life. A sex difference does not exist in panda mutant while adult wild-type male and female are distinguishable by their ventral plumage pattern. Recessive 


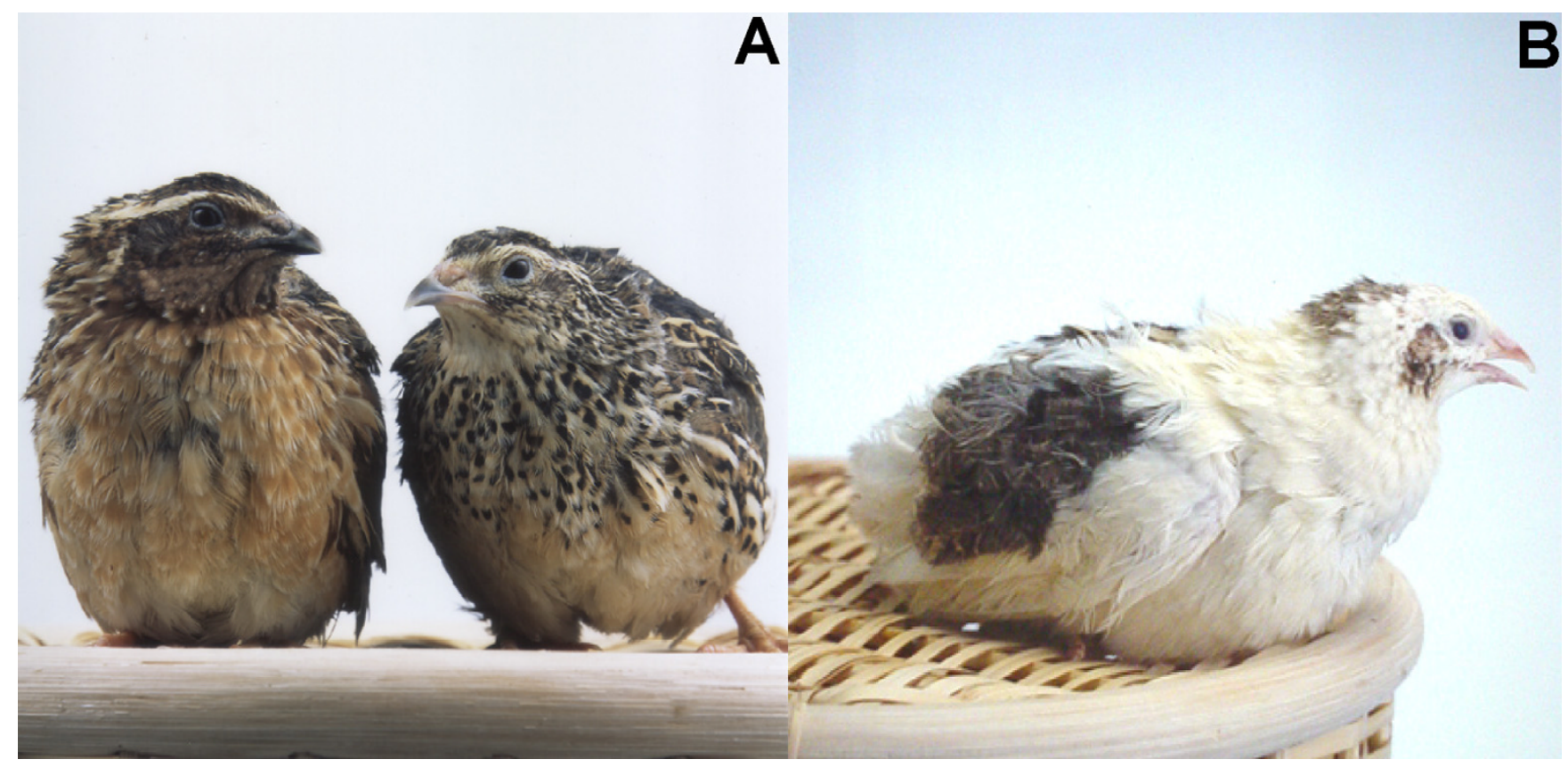

Figure I

The Japanese quail with wild-type (A) and panda (B) plumage color. (A) A male (left) and a female (right) of the Japanese quail with the wild-type plumage. (B) The panda mutant shows overall white with spots of the wild-type plumage. There is no sex difference about the plumage pattern of the panda mutant.

white (wh) [2] and dotted white $\left(s^{d w}\right)[3]$ mutants show phenotypes similar to panda, and $s^{d w}$ has been confirmed to be one of the multiple alleles at the $s$ locus [4]. Although $s$ and $s^{d w}$ mutants show similar phenotypes, they are distinguishable by the location and the size of spot. Because the Japanese quail is a suitable laboratory animal for research and a pilot animal for poultry $[5,6], s, s^{d w}$ and wh mutants have a potential for pigment cell research.

The $s$ locus is included in the same linkage group as two classical markers, serum albumin (Alb) [7] and vitamin-D binding protein $(G C)[8]$, in the Japanese quail. These markers are located on chicken chromosome 4 (GGA4) [9]. Because of high karyotype conservation and orthologous chromosomes between Japanese quail and chicken $[10,11]$, the $s$ locus is likely to be located on chromosome 4 of the Japanese quail (CJA04).

Recently, a microsatellite linkage map was constructed in the Japanese quail [12] and two plumage color loci, black at hatch $(B h)$ and yellow $(Y)$, were mapped on this map [13]. This linkage map was also applied to map quantitative trait loci (QTLs) affecting commercial traits such as growth, feed consumption, egg production, tonic immobility and body temperature [14]. In the present study, to find the responsible gene for the $s$ locus, we tried to map the $s$ locus by the linkage analysis with microsatellite markers located on the candidate chromosome 4. Then, we searched for the candidate gene from the chicken draft genome sequence [15] corresponding to the region where $s$ was mapped in the Japanese quail.

\section{Results and discussion Linkage analysis}

The Q09 linkage group was suggested to be CJA04 because two microsatellite markers on the Q09 were mapped on GGA4 by BLAT search (Table 1) [16]. Thus, the Q09 linkage group was confirmed to be located on CJA04 in this study. Because there are only two microsatellite markers on CJA04, we tried to increase the available microsatellite markers from GGA4. Among thirty chicken microsatellite markers, eight were amplified in the Japanese quail and three were polymorphic in our resource family. Thus two original Japanese quail markers and three original chicken markers were selected for the linkage analysis $[12,17,18]$ (Table 1). These markers were genotyped in the three-generation family for the linkage analysis, and the $s$ locus was linked with GUJ0026, ABR0544, ADL0266 and GUJ0074 (LOD Score $=22.9,21.1,3.90$ and 3.80, respectively). Although no linkage was indicated between $s$ and ADL0255, ADL0255 was linked with GUJ0026 (LOD Score $=3.39$ ). Thus, five microsatellite markers and the $s$ locus were included in one linkage group and the estimated order of loci was ADL0255-GUJ0026-s-ABR0544ADL0266-GUJ0074 (Figure 2). The number of markers located on the CJA04 was increased from two in the pre- 
Table I: Microsatellite markers selected for mapping the $s$ locus.

\begin{tabular}{|c|c|c|c|c|c|c|c|c|}
\hline \multirow[b]{3}{*}{ Locus } & \multirow[b]{3}{*}{ Marker origin } & \multicolumn{4}{|c|}{ Japanese quail } & \multicolumn{3}{|c|}{ Chicken } \\
\hline & & \multirow[b]{2}{*}{$\begin{array}{c}\text { GenBank } \\
\text { accession } \\
\text { number }\end{array}$} & \multirow[b]{2}{*}{$\begin{array}{l}\mathrm{T}_{\mathrm{A}} \\
\left({ }^{\circ} \mathrm{C}\right)\end{array}$} & \multicolumn{2}{|c|}{$\begin{array}{l}\text { Nucleotide similarity between } \\
\text { Japanese quail and chicken (\%) }\end{array}$} & \multirow[b]{2}{*}{$\begin{array}{c}\text { GenBank } \\
\text { accession } \\
\text { number }\end{array}$} & \multirow[b]{2}{*}{ References } & \multirow[b]{2}{*}{$\begin{array}{l}\text { Map position in the draft } \\
\text { sequence of GGA4 (bp) }\end{array}$} \\
\hline & & & & 5' flank & 3' flank & & & \\
\hline ADL0255 & Chicken (GGA4) & $\mathrm{AB} 038396$ & 58 & $83(7 \mid \mathrm{nt})$ & $100(22 \mathrm{nt})$ & $\mathrm{G} 01675$ & {$[17][19]$} & $2,088,640-2,089,022$ \\
\hline GUJ0026 & Quail (CJA04) & AB035836 & 60 & $91(87 \mathrm{nt})$ & $90(50 \mathrm{nt})$ & - & [26] [27] & $10,067,404-10,067,587$ \\
\hline$A B R 0544$ & Chicken (GGA4) & AB220928 & 55 & $89(108 \mathrm{nt})$ & $93(107 \mathrm{nt})$ & $\mathrm{AB} \mid 86688$ & [18] & $|4,275,72|-|4,276,5| \mid$ \\
\hline ADL0266 & Chicken (GGA4) & AB220927 & 50 & $93(15 \mathrm{nt})$ & $89(25 \mathrm{nt})$ & $\mathrm{G} 01686$ & {$[17][18]$} & $45,879,485-45,879,848$ \\
\hline GUJ0074 & Quail (CJA04) & $\mathrm{AB} 063142$ & 59 & $93(253 \mathrm{nt})$ & $83(24 \mathrm{nt})$ & - & [27] & $49,116,133-49,116,445$ \\
\hline
\end{tabular}

Nucleotide similarities of two original Japanese quail markers (GUJ0026 and GUJ0074) were calculated by BLAT search against the chicken draft genome sequence. Nucleotide similarities of three original chicken markers (ADL0255, ABR0544 and ADL0266) were calculated between the GenBank chicken sequence and quail sequence.

vious report [12] to six in the present study. The $s$ locus is an easily distinguishable classical marker, and its assignment to the chromosome will further enhance the usefulness of the linkage map. The serum albumin locus (Alb) was located on GGA4 [9] and was classically linked with the $s$ locus in the Japanese quail [7]. Because classical serum albumin locus (Alb) [7] was monomorphic in our three-generation family, it was not mapped on CJA04 in this study.

\section{Corresponding region on GGA4}

Sequences of PCR products of ABR0544 and ADL0266 amplified from the Japanese quail genomic DNA were very similar to the corresponding chicken sequence indicating that they are orthologous loci (Table 1). ADL0255 was already confirmed to be a cross-species marker for the Japanese quail and chicken [19]. Thus, these three original chicken markers are useful for fine mapping of $s$ in the Japanese quail. By BLAT search, all of the five microsatellite markers were mapped on GGA4 (Table 1) and the order of loci was the same between the Japanese quail and chicken (Figure 2). This result supports that of FISH indicating that CJA04 is homologous to GGA4 and the order of loci in this chromosome pair is conserved $[10,11]$. The distance between ADL0255 and ADL0266 in the Japanese quail linkage map was shorter than that in the chicken consensus linkage map [17]. This result suggests that recombinant frequency of CJA04 is smaller than that of GGA4 (Figure 2).

\section{Candidate gene}

By comparative mapping with chicken, the $s$ locus was suggested to be located between 10.0 Mb (GUJ0026) and $14.5 \mathrm{Mb}$ (ABR0544) in an orthologous region of GGA4 (Figure 2). This region includes the endothelin receptor B subtype 2 gene (EDNRB2) as a candidate gene. EDNRB2 is strongly expressed in neural crest cells, melanoblasts, melanocytes, kidney and liver in the Japanese quail. EDNRB2 appears to be an avian-specific paralog of the mammalian endothelin receptor B (EDNRB) [20]. Alleles of $E D N R B$ are responsible for aganglionic megacolon and spot coat color phenotype in mouse [21], rat [22,23] and equine [24]. Because avian EDNRB2 is not direct orthologue of the mammalian EDNRB [20], mammalian mutations such as aganglionic megacolon in mouse [21] are not exactly analogous to panda in the Japanese quail, even if the $s$ locus does turn out to be in EDNRB2. The association study between EDNRB2 and panda mutation is underway by authors.

\section{Conclusion}

The $s$ locus and five microsatellite markers were included in the same linkage group which was designated as CJA04 in this study. From genome sequence information of the orthologous chicken GGA4, EDNRB2 was suggested to be a candidate gene for the $s$ locus because of its function and chromosome location.

\section{Methods \\ Three-generation family}

A three-generation Japanese quail family was constructed to perform the linkage analysis. One wild-type $(+/+)$ male and one recessive homozygous $(s / s)$ female were mated in the $\mathrm{F}_{0}$ generation to produce $+/ s \mathrm{~F}_{1}$ progeny. Seven $\mathrm{F}_{1}$ birds were single-pair mated with seven $s / s$ birds to produce 46 $+/ s$ and $44 \mathrm{~s} / \mathrm{s}$ birds in the $\mathrm{F}_{2}$ generation. Thus, a total of 106 birds were used as the resource family. Their plumage phenotypes were recognized when they hatched. This three-generation family was not included in any resource population which was used to construct the first-genera- 


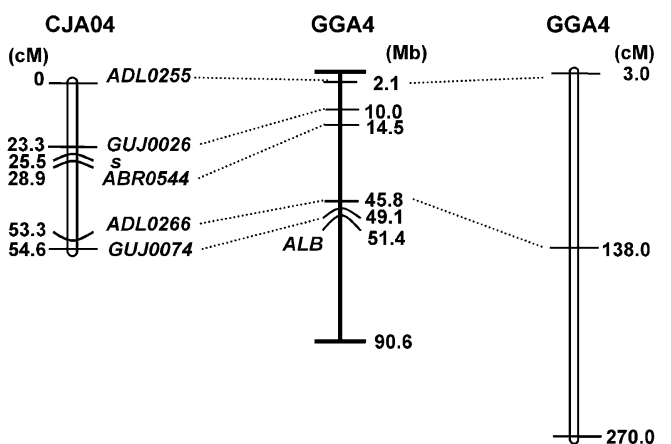

Japanese quail linkage map
Chicken draft genome sequence
Chicken consensus linkage map

\section{Figure 2}

The genetic linkage map of CJA04 and the corresponding position on GGA4. Left: The sex averaged genetic linkage map of CJA04 based on a LOD Score threshold of 3.0 is shown with the estimated Kosambi map distances in cM. Middle: The positions of orthologous loci on the chicken draft genome sequence [9] [15] are shown with the physical map distances in Mb. Right: ADL0255 and ADL0266 were also located on the framework of chicken consensus linkage map with the estimated Kosambi map distances in cM [17]. Microsatellite markers named GUJ are original Japanese quail markers [26] [27] while those named $A D L$ [I7] or $A B R$ [I7] are original chicken markers.

tion microsatellite linkage map of the Japanese quail [12]. DNA was extracted from peripheral blood using QIAamp DNA Blood Kit (Qiagen, Valencia, CA, USA).

\section{Microsatellite markers}

PCR amplifications of five microsatellite markers (Table 1) were carried out on a PCR Thermal Cycler (TaKaRa Biomedicals, Shiga, Japan) in $10 \mu$ reaction mixtures containing $14 \mathrm{ng}$ of the DNA template, $0.3 \mu \mathrm{M}$ of forward and reverse primers, $130 \mu \mathrm{M}$ of $\mathrm{dNTP}, 10 \mathrm{mM}$ Tris- $\mathrm{HCl}(\mathrm{pH}$ 8.3), $50 \mathrm{mM} \mathrm{KCl}, 1.5 \mathrm{mM} \mathrm{MgCl}_{2}$ and $0.4 \mathrm{U}$ AmpliTaq Gold (Perkin-Elmer, Foster City, CA, USA). After an initial incubation at $95^{\circ} \mathrm{C}$ for $9 \mathrm{~min}$, amplification reactions were performed for 30 cycles each with denaturing at $95^{\circ} \mathrm{C}$ for $30 \mathrm{sec}$, annealing for $1 \mathrm{~min}$ at 50 to $60^{\circ} \mathrm{C}$ depending on the optimized annealing temperature of the primer used (Table 1), and extension at $72^{\circ} \mathrm{C}$ for $1 \mathrm{~min}$. This was followed by a final cycle at $72^{\circ} \mathrm{C}$ for $5 \mathrm{~min}$. PCR products were electrophoresed on an ABI Prism 3100 DNA Sequencer (Perkin-Elmer) and analysed using Genescan version 3.7 and the Genotyper version 3.7 softwares (Perkin-Elmer). To confirm whether the chicken primers of ABR0544 and ADL0266 amplified the orthologous Japanese quail microsatellite region, these PCR prod-

uctswere cloned into TA cloning vector pCR2.1 (Invitrogen Corp., CA, USA) and sequenced by the dye termination method using ABI 3100 DNA Sequencer (Perkin-Elmer) (Table 1).

\section{Data analysis}

Linkage analysis was performed based on a LOD Score threshold of 3.0 by CriMap version 2.4 software [25]. To search for the candidate gene, we examined the orthologous positions of the microsatellite markers mapped in the Japanese quail from the chicken draft genome sequence by BLAT search [16]. Because the GenBank sequence of GUJ0026 failed to give a BLAT match to the chicken draft genome sequence, we used longer sequence of GUJ0026 to detect the BLAT match.

\section{Authors' contributions}

MM carried out molecular studies, constructed the Japanese quail family and drafted the manuscript. BBK and HT developed microsatellite markers. NK and MMZ constructed the Japanese quail family. MIM and SI coordinated the study and helped to draft the paper.

\section{Acknowledgements}

We gratefully acknowledge Ms. Y. Ueda for her technical support. This study was partly funded by the 200I, 2002, 2003 and 2004 grants from Gifu University.

\section{References}

I. Mizutani M, Chino K, Umezawa H, Kuramasu S: Genetic analysis of a new plumage - panda in Japanese quail. Exp Anim 1974, 23:59-6I.

2. Cheng KM, Kimura M: Mutations and major variants in Japanese quail. In Poultry Breeding and Genetics Edited by: Crawford RD. Amsterdam: Elsevier; 1990:333-362.

3. Tsudzuki M, Kusano S, Wakasugi N, Morioka H, Esaki K: Dotted white - a plumage color mutant in Japanese quail (Coturnix coturnix japonica). Exp Anim 1992, 41:25-3I.

4. Tsudzuki M, Nakane Y, Wakasugi N, Mizutani M: Allelism of panda and dotted white plumage genes in Japanese quail. J Hered 1993, 84:225-229.

5. Padgett CA, Ivey WD: Coturnix quail as a laboratory research animal. Science 1959, I 29:267-268.

6. Wilson WO, Abbott UK, Abplanalp $\mathrm{H}$ : Evaluation of Coturnix (Japanese quail) as pilot animal for poultry. Poult Sci 196I, 40:65 I-657.

7. Ito S, Kimura M, Isogai I: Linkage between panda plumage and albumin loci in Japanese quail. Jpn J Zootech Sci 1988, 59:822-824.

8. Shibata $T$, Abe T: Linkage between the loci for serum albumin and vitamin $D$ binding protein (GC) in the Japanese quail. Anim Genet 1996, 27:195-197.

9. NCBI Map Viewer [http://www.ncbi.nlm.nih.gov/mapview/ map search.cgi?taxid $=9031$ ]

10. Schmid M, Nanda I, Guttenbach M, Steinlein C, Hoehn M, Schartl M, Haaf T, Weigend S, Fries R, Buerstedde JM, Wimmers K, Burt DW, Smith J, A'Hara S, Law A, Griffin DK, Bumstead N, Kaufman J, Thomson PA, Burke T, Groenen MAM, Crooijmans RPMA, Vignal A, Fillon V, Morisson M, Pitel F, Tixier-Boichard M, Ladjali-Mohammedi K, Hillel J, Maki-Tanila A, Cheng HH, Delany ME, Burnside J, Mizuno S: First report on chicken genes and chromosomes 2000. Cytogenet Cell Genet 2000, 90:169-2I8.

II. Shibusawa M, Minai S, Nishida-Umehara C, Suzuki T, Mano T, Yamada K, Namikawa T, Matsuda Y: A comparative cytogenetic study of chromosome homology between chicken and Japanese quail. Cytogenet Cell Genet 200 I, 95:103-109. 
12. Kayang BB, Vignal A, Inoue-Murayama M, Miwa M, Monvoisin JL, Ito S, Minvielle F: A first-generation microsatellite linkage map of the Japanese quail. Anim Genet 2004, 35:195-200.

13. Miwa M, Inoue-Murayama M, Kayang BB, Vignal A, Minvielle F, Monvoisin JL, Takahashi $H$, Ito S: Mapping of plumage colour and blood protein loci on the microsatellite linkage map of the Japanese quail. Anim Genet 2005, 36:396-400.

14. Minvielle F, Kayang BB, Inoue-Murayama M, Miwa M, Vignal A, Gourichon D, Neau A, Monvoisin JL, Ito S: Microsatellite mapping of QTL affecting growth, feed consumption, egg production, tonic immobility and body temperature of Japanese quail. BMC Genomics 2005, 6:87.

15. International Chicken Genome Sequencing Consortium: Sequence and comparative analysis of the chicken genome provide unique perspectives on vertebrate evolution. Nature 2004 432:695-7I6.

16. UCSC Chicken Genome Browser Gateway [http:// www.genome.ucsc.edu/cgi-bin/hgGateway]

17. ArkDB [http://www.thearkdb.org/]

18. Takahashi H, Tsudzuki M, Sasaki O, Niikura J, Inoue-Murayama M, Minezawa M: A chicken linkage map based on microsatellite markers genotyped on a Japanese Large Game and White Leghorn cross. Anim Genet 2005, 36:463-467.

19. Inoue-Murayama M, Kayang BB, Kimura K, Ide H, Nomura A, Takahashi $H$, Nagamine $Y$, Takeda T, Hanada H, Tatsuda K, Tsudzuki M, Matsuda Y, Mizutani M, Murayama Y, Ito S: Chicken microsatellite primers are not efficient markers for Japanese quail. Anim Genet 200I, 32:7-II.

20. Lecoin L, Sakurai T, Ngo MT, Abe Y, Yanagisawa M, Le Douarin NM: Cloning and characterization of a novel endothelin receptor subtype in the avian class. Proc Natl Acad Sci USA 1998 , 95:3024-3029.

21. Hosoda K, Hammer RE, Richardson JA, Baynash AG, Cheung JC, Giaid $A$, Yanagisawa $M$ : Targeted and natural (piebald-lethal) mutations of endothelin-B receptor gene produce megacolon associated with spotted coat color in mice. Cell I994, 79: | $267-\mid 276$.

22. Gariepy CE, Cass DT, Yanagisawa M: Null mutation of endothelin receptor type $B$ gene in spotting lethal rats causes aganglionic megacolon and white coat color. Proc Natl Acad Sci USA 1996, 93:867-872.

23. Kunieda T, Kumagai T, Tsuji T, Ozaki T, Karaki H, lkadai H: A mutation in endothelin-B receptor gene causes myenteric aganglionosis and coat color spotting in rats. DNA Res 1996, 3:101-105.

24. Metallinos DL, Bowling AT, Rine J: A missense mutation in the endothelin-B receptor gene is associated with Lethal White Foal Syndrome: an equine version of Hirschsprung disease. Mamm Genome 1998, 9:426-431.

25. Green P, Falls K, Crooks S: Documentation for CRI-MAP, version $2.4 \mathrm{St}$ Louis: Washington University School of Medicine; 1990.

26. Kayang BB, Inoue-Murayama M, Nomura A, Kimura K, Takahashi H, Mizutani M, Ito S: Fifty microsatellite markers for Japanese quail. J Hered 2000, 91:502-505.

27. Kayang BB, Inoue-Murayama M, Hoshi T, Matsuo K, Takahashi H, Minezawa M, Mizutani M, Ito S: Microsatellite loci in Japanese quail and cross-species amplification in chicken and guinea fowl. Genet Sel Evol 2002, 34:233-253.
Publish with Biomed Central and every scientist can read your work free of charge

"BioMed Central will be the most significant development for disseminating the results of biomedical research in our lifetime. "

Sir Paul Nurse, Cancer Research UK

Your research papers will be:

- available free of charge to the entire biomedical community

- peer reviewed and published immediately upon acceptance

- cited in PubMed and archived on PubMed Central

- yours - you keep the copyright

Submit your manuscript here:

http://www.biomedcentral.com/info/publishing_adv.asp
BioMedcentral 